\title{
2-Aminotetraline Derivative Protects from Ischemia/ Reperfusion Brain Injury with a Broad Therapeutic Window
}

\author{
Carmen Capone', Cinzia Fabrizi', Paola Piovesan ${ }^{3}$, Maria Cristina Principato', Patrizia Marzorati', \\ Orlando Ghirardi ${ }^{3}$, Lorenzo Fumagalli ${ }^{2}$, Paolo Carminati ${ }^{3}$ and Maria Grazia De Simoni ${ }^{*},{ }^{\prime}$
}

'Department of Neuroscience, Laboratory of Inflammation and Nervous System Diseases, Mario Negri Institute, Milan, Italy; ${ }^{2}$ Department of Cardiovascular, Respiratory and Morphological Sciences, University La Sapienza, Rome, Italy; ${ }^{3}$ R\&D, Sigma-Tau Research Laboratories, Pomezia, Rome, Italy

\begin{abstract}
The effect of ST 1942, a 2-aminotetraline derivative with anti-inflammatory properties, was evaluated in ischemia/reperfusion injury in CD I and C57BL 6 mice. ST 1942 or saline were injected intraperitoneally $30 \mathrm{~min}$ and 6, 24, $36 \mathrm{~h}$ after ischemia. Forty-eight hours after ischemia, ST $1942(25 \mathrm{mg} / \mathrm{kg})$ reduced the infarct volume by 50\% in CDI and 61\% in C57BL/6 mice. All subsequent data were obtained from the latter strain. The ischemic lesion was significantly reduced by $30 \%$ when the first injection was administered $6 \mathrm{~h}$ after ischemia, revealing a broad effective window. Degenerating neurons in striatum, cortex and hippocampus of ischemic mice were markedly decreased by ST 1942. Also examined was the effect of ST 1942 on general and focal neurological deficits for 4 days after ischemia. Mice receiving the drug twice daily showed constantly reduced deficits. We then investigated the cortical mRNA expression of some inflammatory and apoptotic genes by real-time PCR. Forty-eight hours after ischemia STI942 treatment significantly counteracted ischemia-induced activation of $I L-I \beta, T N F \alpha$, and Bax, and enhanced the expression of the antiapoptotic gene, Bcl-2, showing in vivo anti-inflammatory and antiapoptotic actions. The microglial activation/macrophage recruitment in the ischemic lesion was strongly prevented in mice receiving ST 1942. In neuron-microglia cocultures, ST 1942 significantly counteracted LPS-induced cytotoxicity. Binding data and experiments on microglial cell cultures indicate that the anti-inflammatory effect of ST 1942 may be due to its action on 5-HT2B receptors, thus highlighting the possibility that this 5-HT receptor subtype may represent a novel target for neuroprotective drugs in ischemic injury. Neuropsychopharmacology (2007) 32, I302-131 I. doi: I0.1038/sj.npp. I 30 I255; published online 22 November 2006
\end{abstract}

Keywords: 5-HT2B; inflammation; ischemia; microglia; reperfusion; serotonin

\section{INTRODUCTION}

The inflammatory response is a major mechanism in the pathogenesis of brain ischemia/reperfusion injury and represents an interesting target for therapeutic interventions (Allan and Rothwell, 2001; del Zoppo et al, 2000; Dirnagl et al, 1999; Iadecola and Alexander, 2001). At variance with excitotoxicity, which is disruptive but of brief duration, the inflammatory response, after being rapidly triggered, progresses over many hours. It contributes to the evolution of tissue injury by several possible pathways, leading ultimately to activation of apoptotic mechanisms. Soon after ischemia, several inflammatory cascades are initiated. Vascular endothelial cells become rapidly activated, leading to rapid upregulation of adhesion molecules (Connolly et al, 1996; Frijns and Kappelle, 2002; Pantoni

*Correspondence: Dr MG De Simoni, Department of Neuroscience, Laboratory of Inflammation and Nervous System Diseases, Istituto Mario Negri, via Eritrea, 62, Milan 20157, Italy, Tel: + 39 02390 I4505, Fax: + 39 023546277, E-mail: desimoni@marionegri.it

Received 16 May 2006; revised 12 September 2006; accepted 2 October 2006 et al, 1998; Storini et al, 2005). Resident cellular populations, namely astrocytes and microglia, and recruited inflammatory cells, such as neutrophils and macrophages, are triggered to produce an array of inflammatory molecules, including pro-inflammatory cytokines that profoundly affect the pathogenesis of brain injury (Frijns and Kappelle, 2002; Touzani et al, 1999).

Aminotetraline derivatives have previously been reported to possess anti-inflammatory activity, being able to counteract LPS-induced lethality, and cytokine and nitric oxide production (Ruggiero et al, 2004). This in vivo protective effect was possibly mediated by an action on peripheral mononuclear cells. These data indicate that 2 -aminotetraline derivatives may represent novel drugs effective in antiinflammatory strategies.

We set out to determine the effect of ST1942, a 2aminotetraline derivative with anti-inflammatory properties (Piovesan et al, 2003), in a mouse model of ischemia with reperfusion. Indeed, reperfusion, which occurs in human ischemia either spontaneously or as a result of pharmacological thrombolysis, has several important effects on the extent of tissue injury and recovery, particularly with regard to inflammatory events, as it allows the migration of 
inflammatory cells to the site of injury, thus sustaining the inflammatory response. Ischemia was induced in outbred and inbred mouse strains (CD1 and C57BL/6, respectively). The protective effect of different treatment schedules was assessed. The mRNA expression of some inflammatory and apoptotic genes by real-time PCR and the effect on microglial/macrophages were also investigated. In vitro, the ability of ST1942 to counteract LPS-induced toxicity on neuron-microglia cocultures was evaluated. Furthermore, as binding studies indicate that ST1942 binds to 5-HT2B receptors, its effect and that of 5-HT2B agonists and antagonists was explored on LPS-induced TNF- $\alpha$ release from microglial cells providing further details on the possible mechanism of ST1942 neuroprotective action.

\section{MATERIALS AND METHODS}

\section{Animals}

Male C57BL/6 and CD1 mice (26-28 g, Charles River, Calco, Italy) were housed five per cage and kept at constant temperature $\left(21 \pm 1^{\circ} \mathrm{C}\right)$ and relative humidity (60\%) with regular light/dark schedule (0700-1900 hours). Food (Altromin pellets for mice) and water were available ad libitum.

Procedures involving animals and their care were conducted in conformity with institutional guidelines that are in compliance with national (DL n116, GU suppl. 40, 18 February 1992) and international laws and policies (EEC Council Directive 86/609, OJ L 358,1; 12 December 1987; NIH Guide for the Care and Use of Laboratory Animals, US National Research Council 1996).

\section{Transient Focal Cerebral Ischemia}

Ischemia was achieved by middle cerebral artery occlusion as described previously (De Simoni et al, 2004; De Simoni et al, 2003). Anesthesia was induced by $5 \%$ isoflurane in $\mathrm{N}_{2} \mathrm{O} / \mathrm{O}_{2} \quad(70 / 30 \%)$ mixture and maintained by $1.5-2 \%$ isoflurane in the same mixture. To confirm the adequacy of the vascular occlusion in each animal, blood flow was measured by laser Doppler flowmetry (Transonic BLF-21) using a flexible $0.5 \mathrm{~mm}$ fiberoptic probe (Transonic, Type $\mathrm{M}, 0.5 \mathrm{~mm}$ diameter) positioned on the brain surface and secured with impression material on the skull at the following coordinates: $\mathrm{AP}=-1 \mathrm{~mm} ; \mathrm{L}=-3.5 \mathrm{~mm}$. Briefly, the right common carotid artery was exposed and the external carotid artery and its branches, including the occipital artery and the superior thyroid artery, were isolated and cauterized. The pterytopalatine artery was ligated and the external carotid artery cauterized. A 6-0 monofilament nylon suture, blunted at the tip by heat and coated in poly-L-lysine, was introduced into the internal carotid artery through the external carotid artery stump and advanced to the anterior cerebral artery so as to block its bifurcation into the anterior cerebral artery and the MCA. The filament was advanced until a $>70 \%$ reduction of blood flow, compared to preischemic baseline, was observed. At the end of a $15 \mathrm{~min}$ (in C57BL/6 mice) or $30 \mathrm{~min}$ (in CD1 mice) ischemic period, blood flow was restored by carefully removing the nylon filament. During surgery, mice maintained at constant temperature $\left(37 \pm 0.5^{\circ} \mathrm{C}\right)$ using a heating pad equipped with a rectal probe (LSI-Letica, Spain).

\section{Sham-Operated Mice}

Sham-operated mice received a midline neck incision, and the carotid sheath was exposed. The external carotid artery and its branches were isolated without being ligated or cauterized. Similar to ischemic mice, sham-operated mice were maintained at $37^{\circ} \mathrm{C}$ during surgery and recovery from anesthesia.

\section{Drug Treatment}

Mice were injected intraperitoneally (i.p.) with 6.25, 12.5, and $25 \mathrm{mg} / \mathrm{kg}$ of ST1942 ((2S)-(-)-7-acetyl-6-methyl1,2,3,4-tetrahydro-2-naphtalenaminium-chloride, SigmaTau, Pomezia, Italy) or saline according to different administration schedules (times are calculated from the beginning of ischemia): (A) four doses at $30 \mathrm{~min}, 6,24$, and $36 \mathrm{~h}$; (B) four doses at 2, 6, 24, and $36 \mathrm{~h}$; (C) four doses at 4, 8,24 , and $36 \mathrm{~h}$; (D) four doses at 6, 10, 24, and $36 \mathrm{~h}$; (E) four doses at 8, 12, 24, and $36 \mathrm{~h}$; (F) one dose at $30 \mathrm{~min}$; (G) eight doses, starting at $30 \mathrm{~min}$ and $6,24,36,48,60,72,84 \mathrm{~h}$ (ie twice a day for 4 days); (H) two doses at $30 \mathrm{~min}$ and $6 \mathrm{~h}$.

\section{Quantification of Infarct Size and Volume}

Mice were deeply anesthetized with Equitensin $(120 \mu 1 /$ mice i.p.) and brains were rapidly frozen by immersion in isopentane at $-45^{\circ} \mathrm{C}$ for 3 min before being sealed into vials and stored at $-70^{\circ} \mathrm{C}$ until use. For lesion size determination, $40 \mu \mathrm{m}$ coronal brain sections were serially cut at $320 \mu \mathrm{m}$ intervals and stained with neutral red (Neutral Red Gurr Certistain, BDH, England) (De Simoni et al, 2004). On each slice, infarcted areas were assessed blindly and delineated by the relative paleness of histological staining. The infarcted area was determined by subtracting the area of the healthy tissue in the ipsilateral hemisphere from the area of the contralateral hemisphere on each section. Infarct volumes were calculated by the integration of infarcted areas on each brain slice as quantified with computerassisted image analyzer and calculated by Analytical Image System.

\section{Neurological Deficits}

Each mouse was rated once a day on two neurological function scales unique to the mouse (Clark et al, 1997; De Simoni et al, 2004). Mice were scored on both scales from 0 (healthy mouse) to 28 . The score given represents the sum of the results of all categories for each scale. General deficit scale evaluated: hair, ears, eyes, posture, spontaneous activity, epileptic behavior. Focal deficit scale evaluated: body symmetry, gait, climbing onto a surface held at $45^{\circ}$, circling behavior, front limb symmetry, compulsory circling, whisker response to a light touch. All the experiments were run by a trained investigator blinded to the experimental conditions. Differences between ischemic mice receiving ST1942 or saline were analyzed by Friedman test. 


\section{Brain Transcardial Perfusion}

Mice were deeply anesthetized with Equitensin (120 $\mu \mathrm{l} /$ mouse i.p.) and transcardially perfused with $20 \mathrm{ml}$ PBS $0.1 \mathrm{~mol} / \mathrm{l}$, pH 7.4, followed by $50 \mathrm{ml}$ of chilled paraformaldheyde (4\%) in PBS. After carefully removing brains from skulls, they were transferred to $30 \%$ sucrose in PBS at $4^{\circ} \mathrm{C}$ overnight for cryoprotection. Brains were then rapidly frozen by immersion in isopentane at $-45^{\circ} \mathrm{C}$ for $3 \mathrm{~min}$, sealed into vials and stored at $-70^{\circ} \mathrm{C}$ until use.

\section{Fluoro-Jade Labeling}

Fluoro-Jade labeling was carried out on perfused brains (De Simoni et al, 2004; Schmued et al, 1997). Briefly, $20 \mu \mathrm{m}$ mounted sections were dried and dehydrated in ethanol $(100-75 \%)$ and distilled water. They were then incubated in $0.06 \%$ potassium permanganate, washed in distilled water and transferred to $0.001 \%$ Fluoro-Jade staining solution. After staining, the sections were rinsed in distilled water, dried, immersed in xylene, and coverslipped.

\section{Immunohistochemistry}

Twenty-micrometer-thick coronal sections were used for microglia/macrophages immunostaining. Briefly, the sections were rinsed for $30 \mathrm{~min}$ in $0.4 \%$ Triton $\mathrm{X}-100$ in $0.1 \mathrm{~mol} / \mathrm{l} \mathrm{PBS}$ followed by $15 \mathrm{~min}$ in $0.1 \%$ Triton X-100 and $3 \%$ normal goat serum in PBS. The sections were then incubated overnight with the primary monoclonal antibody CD11b, a marker for microglia and macrophages (1:300, a kind gift of Dr A Doni, Mario Negri Institute, Milan, Italy). The next day, the sections were rinsed in PBS before incubation with biotinylated goat anti-mouse secondary antibody for $1 \mathrm{~h}$, washed and incubated with avidin-biotin complex (ABC kit, Vector, UK). After reacting with 3,3'diaminobenzidine tetrahydrochloride (DAB, Vector) the sections were washed, dried, dehydrated through graded alcohols, fixed in xylene, and coverslipped using DPX mountant before light microscopy analysis.

Immunopositive cells were counted in striatum by an image analysis software (AnalySIS). For each mouse three sections, corresponding to coordinates $-1.10 \mathrm{~mm}$, $-0.70 \mathrm{~mm}$, and $-0.20 \mathrm{~mm}$ from bregma, were considered. In each slice, six fields at $\times 20$ were counted. Results are expressed as ratio between immunostained area and the total area of the fields assessed (100\%).

\section{RNA Isolation, cDNA Synthesis, and Real-Time PCR}

Total RNA was isolated from lesioned side cortex according to the acid guanidium-phenol-chloroform method, as shown previously (De Simoni et al, 2000). Complementary DNA was synthesized as follows: $2 \mu \mathrm{g}$ total RNA from each sample was reverse transcribed with random hexamer primers using Multi-Scribe Reverse Transcriptase (TaqMan Reverse transcription reagents, Applied Biosystems, Foster City, CA). The following thermal cycling protocol for reverse transcription was used: $10 \mathrm{~min}$ at $25^{\circ} \mathrm{C}$ for incubation, $30 \mathrm{~min}$ at $48^{\circ} \mathrm{C}$ for reverse transcription, and then $5 \mathrm{~min}$ at $95^{\circ} \mathrm{C}$ for inactivation. Real-time PCR was performed using a GeneAmp 5700 Sequence detection
System (Applied Biosystems, Foster City, CA). Fifty nanograms of cDNA and gene-specific primers $(200 \mathrm{nmol} / \mathrm{l}$ final concentration) were added to Master Mix SYBR Green I Dye, TaqMan DNA polymerase, dNTPs with dUTP, and optimal buffer components (Applied Biosystems, Foster City, CA) and subjected to PCR amplification in a total volume of $25 \mu \mathrm{l}$. The PCR protocol included one cycle at $50^{\circ} \mathrm{C}$ for $2 \mathrm{~min}$, one cycle at $95^{\circ} \mathrm{C}$ for $10 \mathrm{~min}, 40$ cycles at $95^{\circ} \mathrm{C}$ for $15 \mathrm{~s}$ and $60^{\circ} \mathrm{C}$ for $1 \mathrm{~min}$. Real-time PCR was conducted in triplicate with each RNA sample. The amplified transcripts were quantified using the comparative cycle threshold method (Applied Biosystems users bulletin no. 2). Primer optimizing procedures and validation experiments (data not shown) were performed according to the manufacturer's instructions to show that efficiency of target and reference was equal. $\beta$-Actin was used as reference gene and relative gene expression levels were determined according to manufacturer's $\Delta \Delta C_{\mathrm{t}}$ method (Applied Biosystems). Primers were designed using Primer Express software (Applied Biosystems, Foster City, CA) based on GenBank accession numbers (Table 1).

\section{Binding assays}

${ }^{125}$ I]DOI binding assays. CHO cells transfected with human serotonin 5HT2B receptors were used and DOI binding assay was performed as described previously (Choi et al, 1994). Briefly, the incubation medium $(200 \mu \mathrm{l})$ contained $50 \mu \mathrm{l}$ of radioligand $(0.2 \mathrm{nM}$ of DOI), $50 \mu \mathrm{l}$ of buffer $(50 \mathrm{mmol} / \mathrm{l}$ Tris buffer, $\mathrm{pH}$ 7.4) alone or containing competing drug, and $100 \mu \mathrm{l}$ of membrane suspension (protein concentration, $50 \mu \mathrm{g} / \mathrm{ml}$ ). The mixture was incubated at $37^{\circ} \mathrm{C}$ for $15 \mathrm{~min}$. Nonspecific binding, determined in the presence of $1 \mu \mathrm{mol} / 1$ unlabeled DOI, represented about $30 \%$ of total binding.

Competition studies for DOI binding were performed by adding increasing concentrations ( 8 points from $3.0 \mathrm{E}-08$ to $1.0 \mathrm{E}-04 \mathrm{~mol} / \mathrm{l})$ of ST1942 to the reaction.

The $\mathrm{IC}_{50}$ values and Hill coefficients $\left(n_{\mathrm{H}}\right)$ were determined by nonlinear regression analysis of the competition curves using Hill equation curve fitting. As the Hill

Table I Primers used for quantitative real-time polymerase chain reaction analysis of $\beta$ actin, TNF- $\alpha, I L-I \beta, B C l-2$, and Bax transcript levels

\begin{tabular}{llc}
\hline CDNA & Sequence $\mathbf{( 5}^{\prime}$ to $\mathbf{3}^{\prime}$ ) & $\begin{array}{c}\text { Amplified } \\
\text { region }\end{array}$ \\
\hline$\beta$-Actin (NM007393) & GCCCTGAGGCTCTTTCCAG (fwd) & $850-900$ \\
& TGCCACAGGATCCATACCC (rev) & \\
TNF- $\alpha$ (NM0 13693) & ATGCTGGGACAGTGACCTGG (fwd) & I042-1092 \\
& CCTTGATGGTGGTGCATGAG (rev) & \\
IL-I $\beta$ (NM00836I) & TAACCTGCTGGTGTGTGCGT (fwd) & $333-383$ \\
& CGGAGCCTGTAGTGCAGTTGT (rev) & \\
BCl-2 (NM00974I) & GTGAACTGGGGGAGGATTGT (fwd) & $385-435$ \\
& GGAGAAATCAAACAGAGGCC (rev) & \\
Bax (NM007527) & GGAGCAGCTTGGAGGCG (fwd) & I24-I44 \\
& AAAAGGCCCCTGTCTTCATGA (rev) & \\
\hline
\end{tabular}

fwd, forward; rev, reverse primers. 
coefficient was not significantly different from 1 , the dissociation constant $\left(K_{\mathrm{i}}\right)$ of ST1942 was calculated from $\mathrm{IC}_{50}$ according to the Cheng Prusoff equation.

Other binding and enzyme assays. The following binding affinity studies have been also carried out: (A) non-peptide receptors: adenosine: $\mathrm{A} 2 \mathrm{~A}$; adrenergic: $\alpha 1, \beta 1, \beta 2, \beta 3$; cannabinoid: CB1, CB2; dopamine: D1, D2, D3; histamine: $\mathrm{H} 1$ peripheral, $\mathrm{H} 2, \mathrm{H} 3$; muscarinic: $\mathrm{M} 1, \mathrm{M} 2, \mathrm{M} 4, \mathrm{M} 5$; serotonin: 5-HT1A, 5-HT1B, 5-HT1D, 5-HT2A, 5-HT2C; (B) peptide receptors: angiotensinII: AT1; bradykinin: $\mathrm{B} 2$; complement 5a: C5A; cytokines: IL- $1 \beta$, TNF $\alpha$; neurokinin: NK1; (C) ion channels: membrane ligand-gated channels: BZD central, GABA $A_{A}$ AMPA, kainate, NMDA; voltage-gated channels: $\mathrm{Ca}^{2+}$ channel L, $\mathrm{Ca}^{2+}$ channel $\mathrm{N}$; (D) enzymes: protein serine/threonine kinases: JNK3, Akt1, Akt2, Akt3, PKC, $\mathrm{PKC} \alpha, \operatorname{PKC} \beta 1, \operatorname{PKC} \beta 2, \operatorname{PKC} \delta, \operatorname{PKC} \gamma$; NO synthases: constitutive NOS (endothelial and cerebellar); phosphodiesterases: PDE1, Rolipram; (E) amine transporters: norepinephrine; (F) steroid nuclear receptors: glucocorticoid.

All binding assays were carried out by CEREP (France) in accordance to their standard operating procedures.

\section{Cell Cultures}

Primary microglial cells were derived from postnatal days 3-4 rat cortex as described previously (Aloisi et al, 1998; Novarino et al, 2004). Free-floating microglia were collected from shaken astrocyte flasks, seeded onto 24-well plates $\left(3 \times 10^{5}\right.$ cells/well) and maintained in DMEM (Invitrogen, Milan, Italy) supplemented with $10 \%$ fetal calf serum (FCS) (Invitrogen, Milan, Italy) in 5\% CO2. The purity of microglial cultures was assessed by a positive staining for Griffonia simplicifolia isolectin B4 (Vector Laboratories, Burlingame, CA). The murine microglial cell line BV-2 (Blasi et al, 1990) was grown in DMEM supplemented with $10 \%$ FCS in $5 \% \mathrm{CO}_{2}$.

Microglial primary cultures or BV-2 cells were treated for $1 \mathrm{~h}$ with $50 \mathrm{ng} / \mathrm{ml}$ Escherichia coli LPS alone or in combination with $0.01,0.1,1,10 \mu \mathrm{mol} / 1$ ST1942, SB204741 (5-HT2B antagonist), or $\alpha$-methylserotonin maleate (5-HT2B agonist) (both Sigma-Aldrich, Milan, Italy). After stimulation, culture supernatants were removed, centrifuged at $500 \mathrm{~g}$ for $5 \mathrm{~min}$ to remove cellular debris and kept at $-80^{\circ} \mathrm{C}$ until assayed by a specific ELISA kit (R\&D Systems, Abington, UK). TNF- $\alpha$ shedding was observed by treating microglial cells with $50 \mathrm{nmol} / \mathrm{l} \alpha$-methylserotonin maleate for $1 \mathrm{~h}$ alone or in combination with $200 \mathrm{nmol} / \mathrm{l}$ ST1942. The release of TNF- $\alpha$ in culture media was assayed as described previously. Primary hippocampal neurons were prepared from embryonic day 18 rat brain (Goslin and Banker, 1990; Hansen et al, 1989). After dissection, the hippocampi were treated with 2.5\% trypsin and dissociated with a flame-polished Pasteur pipette. The cells were plated onto poly-L-lysine-treated glass coverslips $\left(2 \times 10^{5}\right.$ cells/well $)$ in Minimum Essential Medium (Life Technologies Inc.) containing 10\% FCS. After $2 \mathrm{~h}$, the medium was substituted with Neurobasal-A/B27 (Life Technologies Inc.). After $8 \mathrm{~h}$ from seeding $5 \mu \mathrm{M}$ arabinosylcytosine was added. Neuronal cell cultures contained less than $1 \%$ of astrocytes, as shown by glial fibrillary acidic protein (GFAP) staining (data not shown). For neuronmicroglia cocultures coverslips were transferred to the 24- well plates containing the microglial cells $\left(2 \times 10^{5}\right.$ cells/well $)$, facing down, on top of paraffin drops. These cultures were treated for $24 \mathrm{~h}$ with 0.1 or $1 \mu \mathrm{g} / \mathrm{ml} \mathrm{E}$. coli LPS alone or in combination with $50 \mu \mathrm{mol} / 1 \mathrm{ST} 1942$.

Cell viability was assessed by lactate dehydrogenase $(\mathrm{LDH})$ release in the culture medium. It was measured by Cytotoxicity Detection Kit (Roche, Mannheim, Germany) according to manufacturer's protocols. Cell viability was also measured by MTT reduction essentially as described (Hansen et al, 1989). LDH assay was performed on culture medium shared by neurons and microglia, whereas for MTT test neurons were separated from microglia before cell lysis.

\section{RESULTS}

\section{Infarct Volume and Neurodegeneration}

ST1942 is able to reduce the ischemic volume in a dosedependent way (Figure 1a). Using the most effective dose
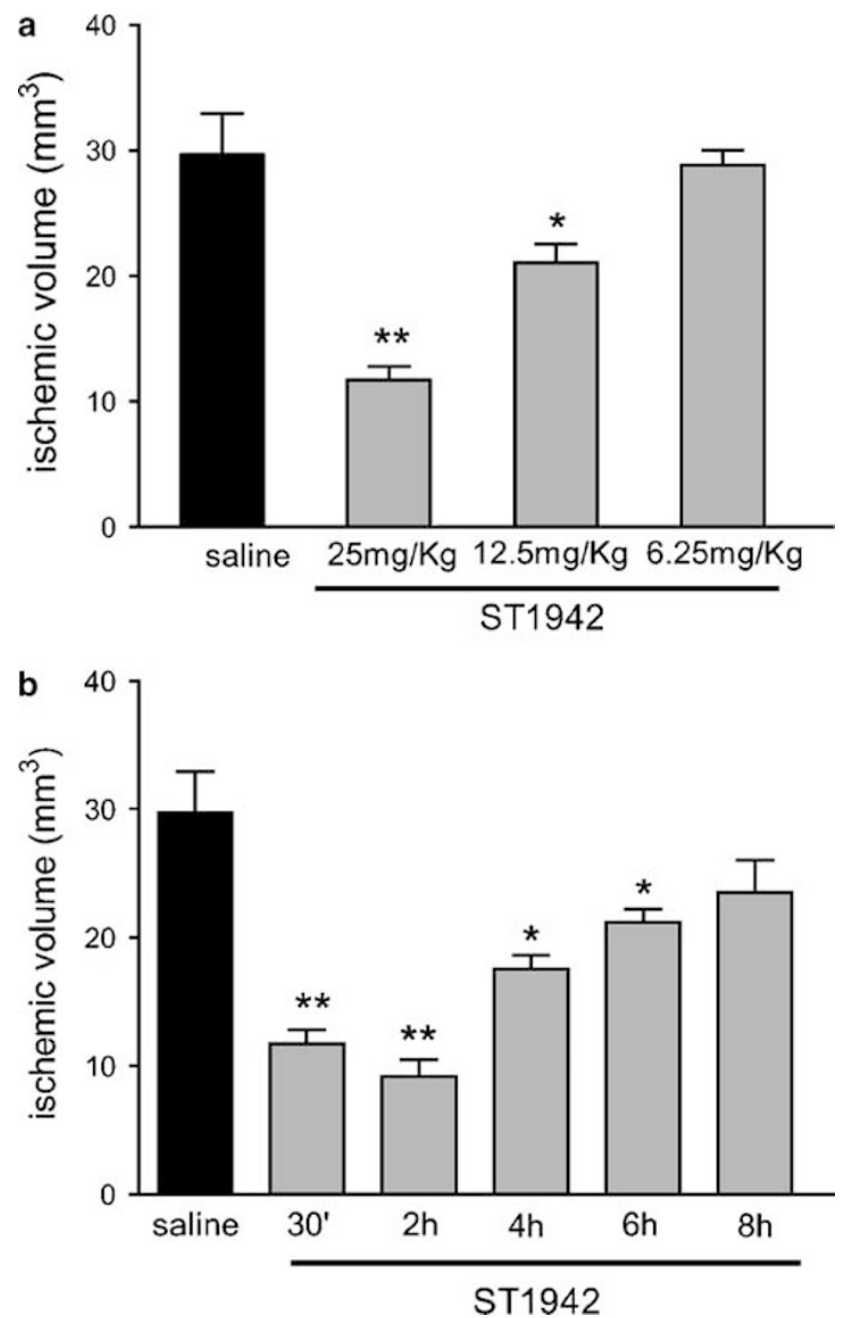

Figure I ST1942 reduces the infarct volume assessed $48 \mathrm{~h}$ after ischemia lesion in C57BL/6 mice. (a) Effect of ST 1942 in mice subjected to ischemia and $48 \mathrm{~h}$ of reperfusion receiving saline or ST 1942 at 25 or 12.5 or $6.25 \mathrm{mg} / \mathrm{kg}$ at $30 \mathrm{~min}, 6,24$, and $36 \mathrm{~h}$ after beginning of ischemia. (b) Effective-window of ST $1942(25 \mathrm{mg} / \mathrm{kg})$ in mice receiving four saline or STI942 doses, the first dose $30 \mathrm{~min}$ or $2,4,6,8 \mathrm{~h}$ after beginning of ischemia. Data are expressed as mean \pm SEM, $n=5-7$. *** $p<0.01$, * $p<0.05$ vs saline, Mann-Whitney test. 
$(25 \mathrm{mg} / \mathrm{kg})$, we have analyzed the effect of different treatment schedules on the infarct lesion in C57BL/6 mice. At $48 \mathrm{~h}$ from ischemia, in ischemic mice receiving four doses of the drug, (schedule A) the infarct volume decreases by $61 \%$ (ST1942: $11.7 \pm 2.7 \mathrm{~mm}^{3}$ ). A significant reduction of the infarct lesion is still present when the first dose is delayed to 2,4 , and $6 \mathrm{~h}$ after ischemia $\left(2 \mathrm{~h}: 9.14 \pm 2.9 \mathrm{~mm}^{3}\right.$; 4 h: $17.5 \pm 2.6 \mathrm{~mm}^{3}$; $6 \mathrm{~h}: 21.15 \pm 3.0 \mathrm{~mm}^{3}$, schedules B, C, D, respectively, Figure $1 \mathrm{~b}$ ). A decrease, although not statistically significant, is still present when the first dose is delayed $8 \mathrm{~h}$ after ischemia (schedule $\mathrm{E}$ ). The effect of a single dose of the drug given $30 \mathrm{~min}$ after ischemia has also been assessed $48 \mathrm{~h}$ after ischemia (schedule F). It reduces the ischemic lesion by $21 \%$ (saline: $29.7 \pm 7.8 \mathrm{~mm}^{3}$; ST1942: $23.6 \pm 4.1 \mathrm{~mm}^{3}$ ), a nonsignificant decrease (data not shown).
As different strains of mice may respond differently to the ischemic insult, we also analyzed the effect of ST1942 in $\mathrm{CD} 1$ mice. In these mice, $48 \mathrm{~h}$ after ischemia, the same treatment significantly reduces the ischemic lesion by $50 \%$ (saline: $105.48 \pm 12 \mathrm{~mm}^{3}$; ST1942: $52.70 \pm 16.32 \mathrm{~mm}^{3}$, data not shown) indicating that ST1942 can markedly reduce the ischemic volume in both inbred (C57BL/6) and outbred (CD1) mice. Except for this experiment, all others were performed in C57BL/6 mice.

We then evaluated the effect of ischemia and ST1942 treatment on neurodegeneration to determine if neurons are actually spared by drug treatment. Typically, the ischemic protocol used induces neurodegeneration in striatum and, to a lesser extent, in cortex and hippocampus. As expected, $48 \mathrm{~h}$ after ischemia, Fluoro-Jade staining, a
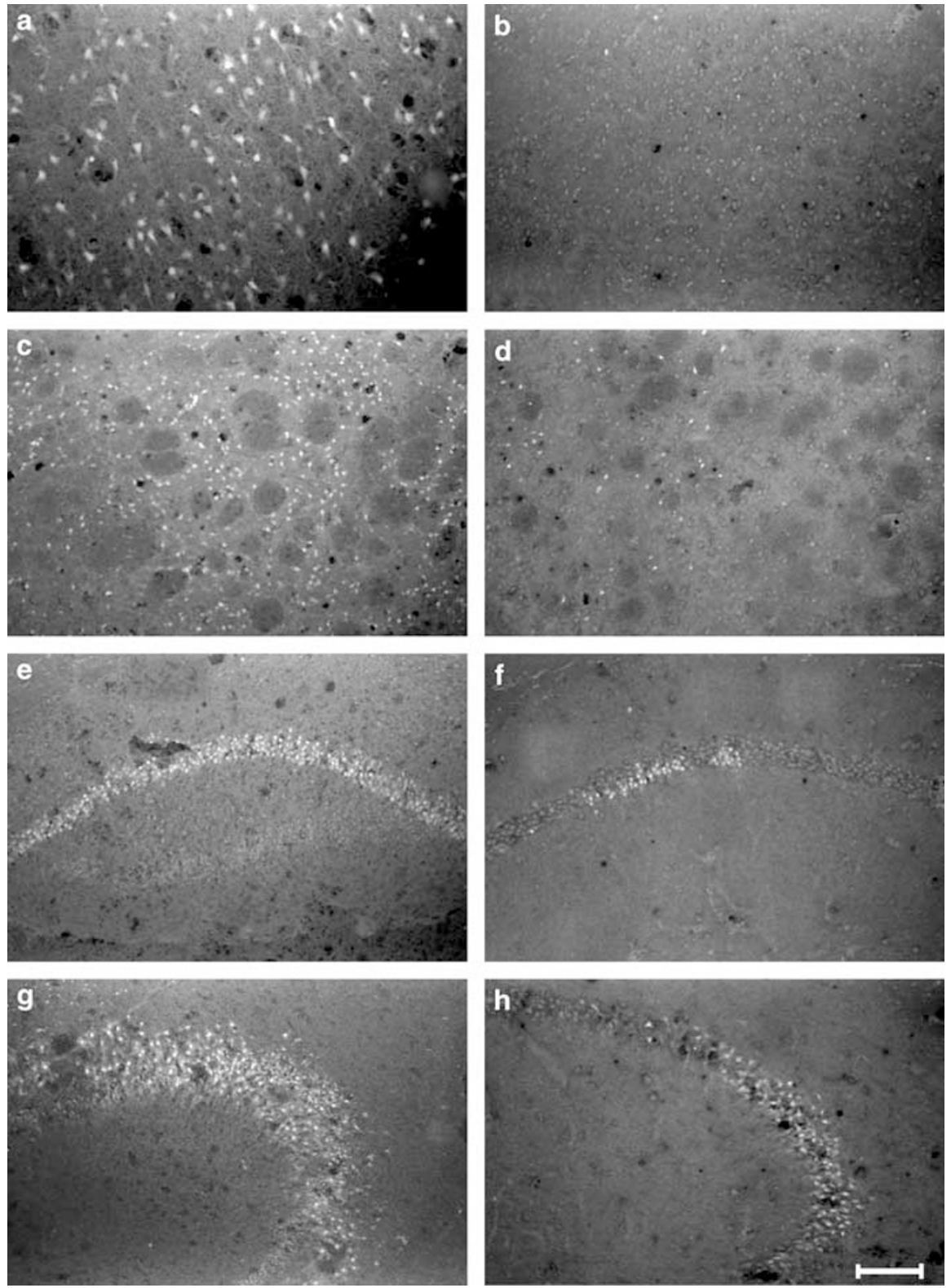

Figure 2 Fluoro-Jade labeling of degenerating neurons $48 \mathrm{~h}$ after ischemia in different brain areas of representative mice receiving saline (a, c, e, and $\mathrm{g}$ ) or ST 1942 (25 mg/kg, b, d, f, and h) at $30 \mathrm{~min}, 6,24$, and $36 \mathrm{~h}$ after beginning of ischemia. Few scattered Fluoro-Jade positive neurons (b, d) or small groups of positive pyramidal cells $(f, h)$ can be observed in treated mice, whereas several positive neurons are present in the corresponding areas of saline-treated ischemic mice. (a, b) Cortex; (c, d) striatum; (e, f) hippocampus, CAI; (g, h) hippocampus, CA3. Bar = I00 $\mu$ M. 
neurodegeneration marker, reveals the presence of degenerating neurons in these brain areas. In saline-treated mice, positive cells are constantly observed in the parietal cortex and in striatum where they appear as extended clusters of positive cells (Figure 2a and c). Several fluorescent cells are also present in hippocampus, including CA1 (Figure 2e), CA2, CA3 (Figure 2g), and dentate gyrus. In mice treated with ST1942, the number of degenerating cells is greatly reduced. Few positive cells are still present in cortex and striatum (Figure 2b and $\mathrm{d}$ ) and only a few groups of fluorescent pyramidal neurons are present in hippocampus (Figure 2f and h), showing that ST1942 markedly reduces the number of degenerating cells.

\section{Neurological Deficits}

To evaluate if the marked reduction of the ischemic lesion produces an improvement in functional impairment, neurological deficits were evaluated every day for 4 days in ischemic mice receiving saline or ST 1942 according to the same protocol as in Figures $1 \mathrm{a}$ and 2 except that the treatment was continued every $12 \mathrm{~h}$ from the $36 \mathrm{~h}$ time point to $84 \mathrm{~h}$ (schedule $\mathrm{G}$ ). Both general and focal neurological deficits are significantly improved (Figure 3 ). The effect is apparent already at the first test at $24 \mathrm{~h}$.

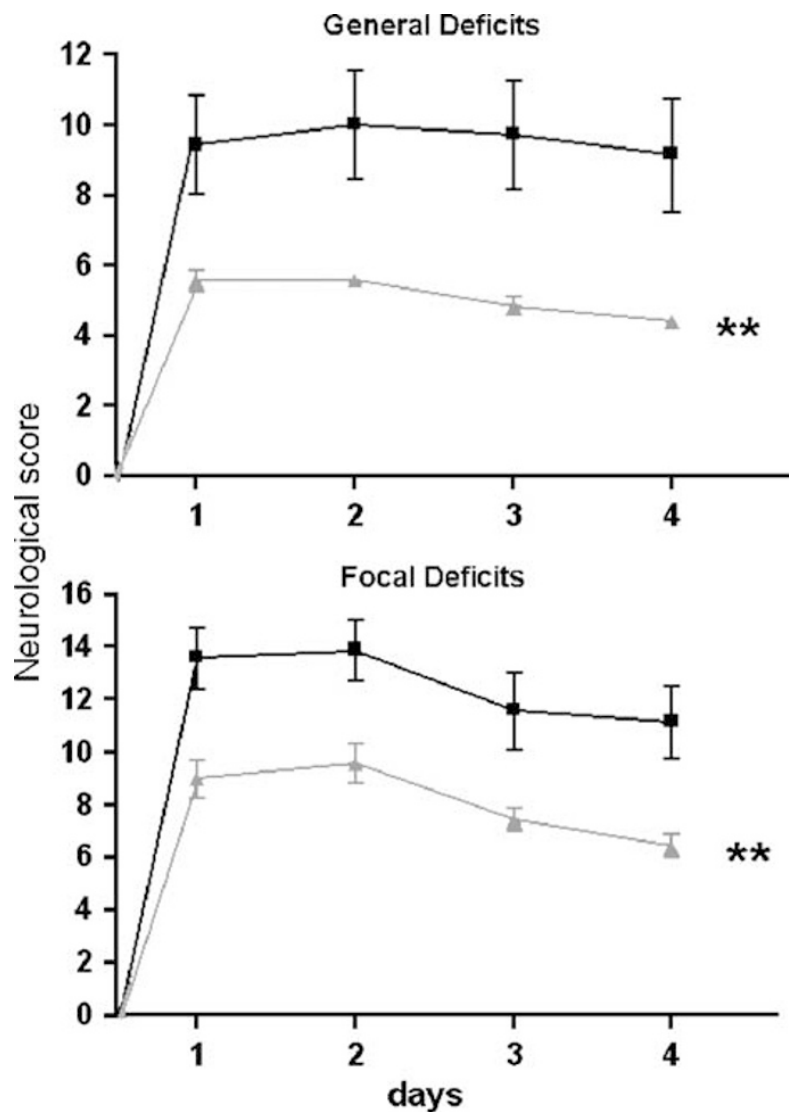

Figure 3 General and focal neurological score evaluation assessed daily in ischemic mice receiving saline (black line) or $25 \mathrm{mg} / \mathrm{kg} \mathrm{ST} 1942$ (gray line) twice a day for 4 days. Mice were scored from 0 (healthy) to 28 and data are expressed as mean \pm SEM, $n=7$. Difference between curves is evaluated by two-way ANOVA for repeated measures. $F$ interaction: *** $p<0.01$.

\section{Gene Expression Data}

To investigate the neuroprotective mechanisms of ST1942, we analyzed some genes activated by ischemia 24 and $48 \mathrm{~h}$ after surgery (schedules $\mathrm{H}$ and $\mathrm{A}$, respectively) in the cortex of ischemic and sham-operated mice (Figure 4). With the ischemic protocol used, this brain area typically includes a portion of the lesion, as well as the penumbra, where the tissue is functionally impaired but potentially salvageable and is well suited for studying ischemic gene expression (Storini et al, 2005).

The mRNA expression of the inflammatory cytokines TNF- $\alpha$ and IL- $1 \beta$ are significantly upregulated by ischemia compared to sham-operated mice both at 24 and $48 \mathrm{~h}$. ST1942 treatment significantly prevents the upregulation of these cytokines at both time points (Figure 4).

The expression of the antiapoptotic gene $\mathrm{Bcl}-2$ is decreased at $24 \mathrm{~h}$ in ischemic mice. At this time point, the drug treatment does not change this effect. At $48 \mathrm{~h}$, instead, the expression of this protective gene is markedly enhanced by treatment with the drug. At the same time point, the ischemia-induced activation of the proapoptotic gene Bax is prevented by ST1942 treatment, which dampens its expression compared to ischemic and to sham-operated mice (Figure 4).

\section{Microglia/Macrophage Cell Activation}

Ischemic mice show a strong cell activation and/or infiltration of microglia/macrophages. Forty-eight hours after ischemia CD11b-positive cells are larger in size and increased in number compared to sham-operated mice. ST1942 is able to markedly reduce the number of positive cells throughout the lesioned area (Figure 5).

\section{Binding Studies}

Results from binding assays indicate that ST1942 inhibits DOI binding to human $5 \mathrm{HT} 2 \mathrm{~B}$ receptors in transfected $\mathrm{CHO}$ cells with a $K_{\mathrm{i}}$ of $2.8 \times 10^{-7}$. The drug does not displace DOI in non-transfected cells (data not shown).

The binding assay screening carried out (see Materials and methods) revealed that ST1942 had $>10^{-5}$ affinity for all the other binding sites assessed, including serotonin: 5-HT1A, 5-HT1B, 5-HT1D, 5-HT2A, 5-HT2C (data not shown).

\section{Effects of ST1942 and 5-HT2B Drugs on Microglial Cells}

To test the hypothesis that ST1942 can modulate the inflammatory response by acting on microglial cells, which are the inflammatory cells of the brain, we evaluated its effect on LPS-induced TNF- $\alpha$ release in primary microglial cells and in BV-2 microglial cell line. ST1942 dosedependently reduces TNF- $\alpha$ release in both primary microglia (Figure 6a) and BV-2 cells (data not shown) challenged with LPS. The suppression of TNF- $\alpha$ production is not caused by any toxicity associated with ST1942 as confirmed by MTT assay and LDH release (data not shown). We then tested the ability of 5-HT2B agonists and antagonists to modify LPS-induced TNF- $\alpha$ release in microglia. The 5-HT2B antagonist SB204741 inhibits TNF- 

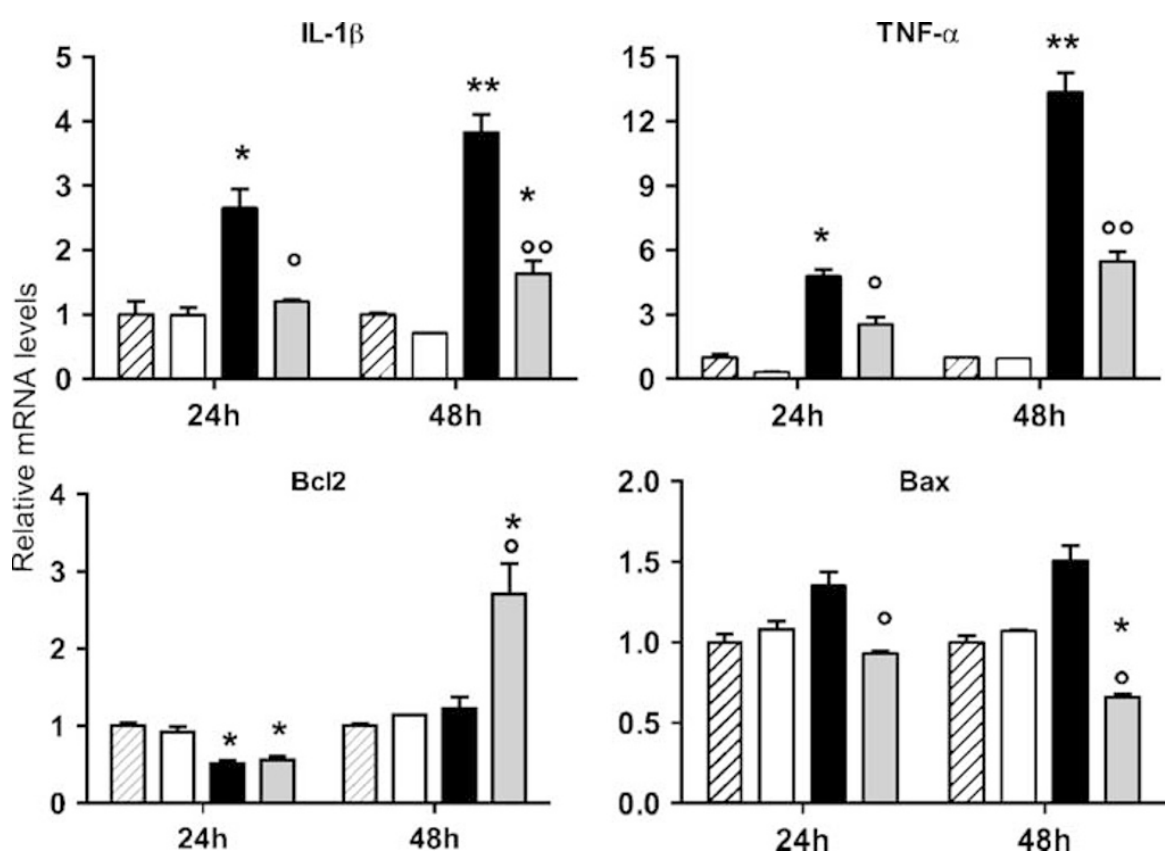

Figure 42 -aminotetraline in ischemic injury mRNA expression of IL-I $\beta, T N F-\alpha, B c l-2$, and Bax determined 24 and $48 \mathrm{~h}$ after ischemia by real-time PCR on cortices of sham-operated or ischemic mice receiving saline (sham-operated: striped bars; ischemic: black bars) or STI942 (25 mg/kg, sham-operated: white bars; ischemic: gray bars) at $30 \mathrm{~min}, 6,24$, and $36 \mathrm{~h}$ after beginning of ischemia. Data are expressed as mean \pm SEM (four to five mice per group) ${ }^{*} p<0.05$ and ${ }^{*} * p<0.01$ vs corresponding sham operated, ${ }^{\circ} p<0.05$ and ${ }^{\circ} p<0.01$ vs ischemic mice receiving saline, ANOVA followed by Tukey's post hoc test.

$\alpha$ production in LPS-stimulated cells, whereas the 5-HT2B agonist $\alpha$-methylserotonin maleate is ineffective. On the contrary, at 1 and $10 \mu \mathrm{mol} / \mathrm{l} \alpha$-methylserotonin maleate determines an increased release of TNF- $\alpha$ compared to control (Figure 6b). Moreover, treatment of primary microglial cells with $\alpha$-methylserotonin maleate alone for $1 \mathrm{~h}$ induces TNF- $\alpha$ release in the culture media and this effect is blocked by ST1942 (Figure 6c). Although $\alpha$ methylserotonin maleate has affinity to many $5-\mathrm{HT}$ receptors, our binding studies performed on a large number of receptors show that ST1942 has a very low affinity for 5-HT1A, 5-HT1B, 5-HT1D, 5-HT2A, and 5-HT2C (see Materials and methods).

In cocultures of hippocampal neurons and microglia an increased release of LDH in the culture medium is observed after LPS treatment, which can be reduced by ST1942 (Figure 7a) indicating a neuroprotective effect of this compound. No release of LDH is observed in LPS-treated microglia and neurons cultured separately (data not shown). The MTT assay confirms that neuronal death induced by LPS is significantly attenuated by ST1942 (Figure $7 b$ ).

\section{DISCUSSION}

The present study demonstrates that the 2-aminotetraline derivative ST1942 effectively prevents tissue damage and neurological deficits in ischemic brain. The ability of the compound to reduce the ischemic lesion was shown both in C57/BL6 and in CD1 mice, that is, inbred and outbred strains. Notably, when given at $25 \mathrm{mg} / \mathrm{kg}$, a significant reduction of ischemic volume was evidenced when the first dose was given up to $6 \mathrm{~h}$ after injury.

The use of Fluoro-Jade staining to show degenerating neurons allowed us to investigate whether ST1942 action could spare these cells. A marked decrease in the number of Fluoro-Jade-positive cells was observed throughout different brain areas, striatum, cortex, and hippocampus in treated mice, indicating that neurodegeneration was actually inhibited by ST1942.

An important aspect when assessing the protective effect of a compound on ischemia/reperfusion injury is the evaluation of its ability to affect functional deficits. The monitoring of general and focal neurological deficits clearly showed that ischemic mice receiving the drug, showing improvement in appearance and motor performance, were significantly protected compared to saline-treated mice. Importantly, this effect, apparent at just $24 \mathrm{~h}$ after ischemic injury, was persistent and observed throughout the experiment (4 days).

Thus, the data obtained clearly indicate that ST1942 has strong protective properties and a broad effective window (at least $6 \mathrm{~h}$ ) in ischemia/reperfusion brain injury.

To identify targets of ST1942 action that can account for its neuroprotective effect in ischemia/reperfusion injury, we analyzed the cortical mRNA expression of some genes activated by ischemia/reperfusion (Storini et al, 2005) and investigated possible modulating effects of the compound at two time points from ischemia. The results show that ST1942 has anti-inflammatory and antiapoptotic properties and that inhibition of inflammation is an early target of ST1942 action. In fact ST1942 significantly reduces the upregulation of the inflammatory cytokines TNF- $\alpha$ and 

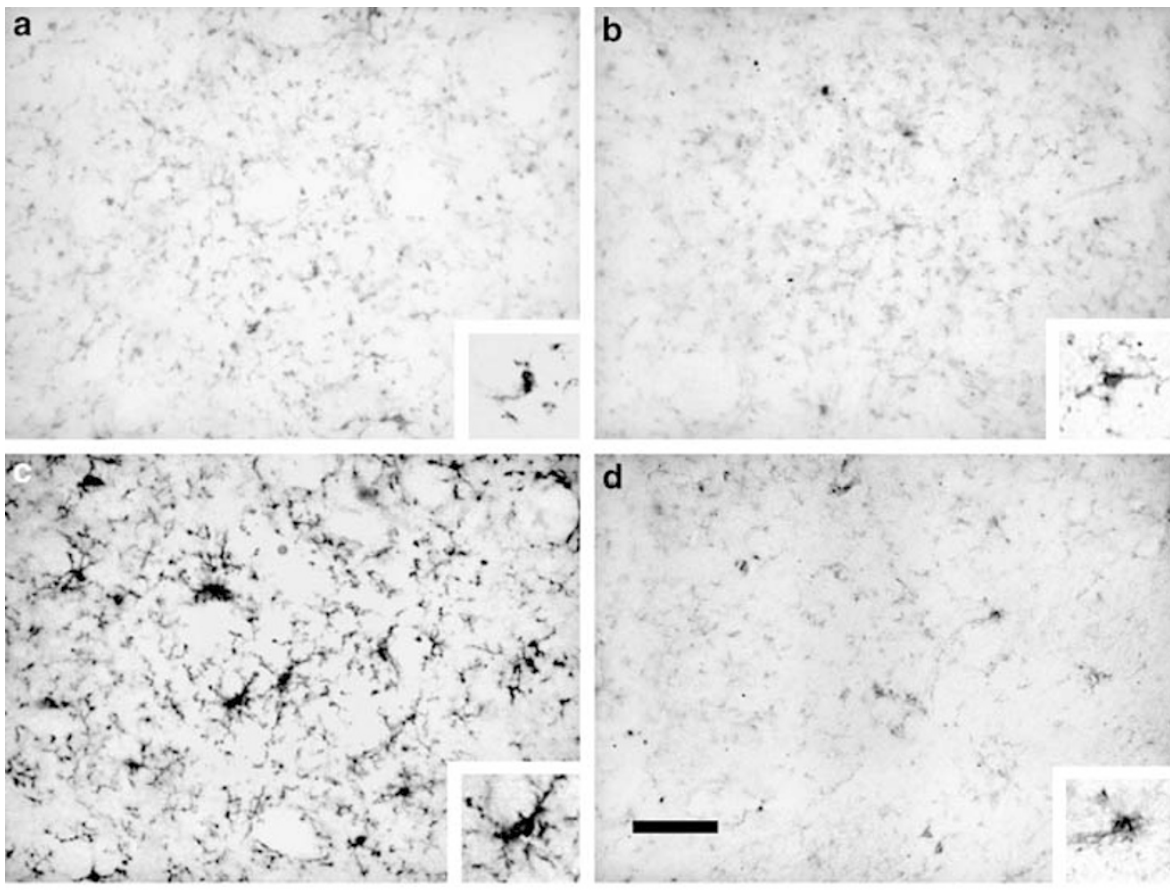

e

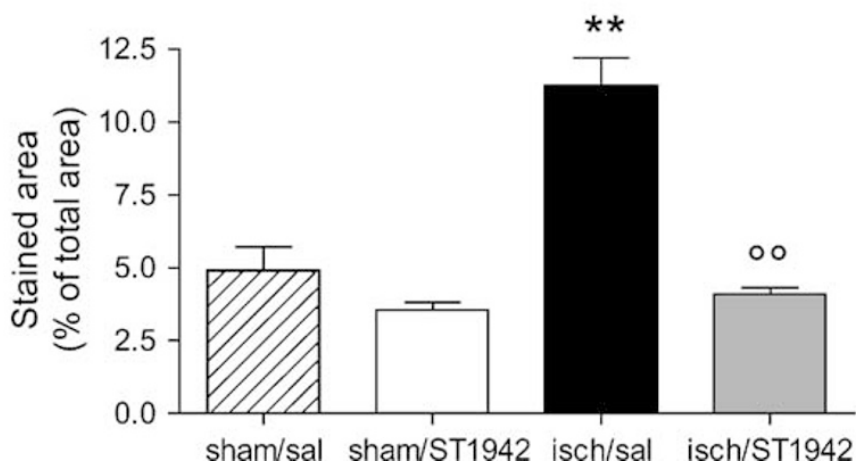

Figure 5 ST1942 reduces microglia/macrophage activation /infiltration after ischemia. (a-d) CDI lb positive cells in representative sections of injured striatum in sham-operated or ischemic mice receiving saline (a and c, respectively) and in sham-operated or ischemic mice receiving ST I 942, $25 \mathrm{mg} / \mathrm{kg}$ (b and $\mathrm{d}$, respectively) (scale bar $=100 \mu \mathrm{m}$ ). (e) Quantification of CDIIb-positive cells in ischemic striatum. Values are the mean \pm SEM. $* * * 0.01$ vs shamoperated receiving saline or STI942, ${ }^{\circ} \mathrm{p}<0.0 \mathrm{I}$ vs ischemic mice treated with saline, ANOVA followed by Tukey's post hoc test.

IL- $1 \beta$ observed as early as $24 \mathrm{~h}$ after injury and later on at $48 \mathrm{~h}$. Instead, analysis of the expression of genes related to apoptosis (Troglio et al, 2004) revealed that 48 , but not $24 \mathrm{~h}$ from ischemia, ST1942 decreases the expression of the proapoptotic gene Bax and increases that of the antiapoptotic Bcl-2 thus inducing a shift from a pro- to an antiapoptotic status. Notably, the decrease in Bax and the increase in $B c l-2$ expression are wide and do not simply restore the expression observed in sham operated experimental groups. This may be possibly due to a modulation of $B a x$ and $B c l-2$ gene expression in astrocytes, a cell population that is activated by ischemia. Further experiments are needed to fully substantiate this hypothesis.

In the ischemic brain, microglial cells are rapidly and persistently activated, being, together with macrophages recruited from blood stream, the major effectors of the brain inflammatory response (Becher et al, 2000). Consistently with the inflammatory gene evaluation described above, ST1942 markedly prevents the microglia/macrophages activation/recruitment further showing a potent anti-inflammatory action. The complex role of the inflammatory response in acute brain injury and specifically of the inflammatory cells is still an open question (del Zoppo et al, 2001; Feuerstein and Wang, 2001; Neumann et al, 2006). Both our in vivo and in vitro data indicate that microglial cells are a target of the aminotetraline protective action. Actually, the drug effectively prevents LPS-induced neuronal cell death in neuron-microglia cocultures. Moreover, the data obtained on microglial cell cultures show that ST1942 exerts its anti-inflammatory effect by direct action on these cells. In fact, exposure to ST1942 induces a dose-dependent decrease in LPS-induced TNF- $\alpha$ release. Taking into account that our aminotetraline derivative binds 5-HT2B receptors, we tested the hypothesis that it could act through these receptors. Actually, similarly to ST1942, a 5-HT2B antagonist inhibits TNF- $\alpha$ release in LPS-treated microglia. In addition, ST1942 is able to inhibit TNF- $\alpha$ shedding induced in microglia by a 5-HT2B agonist. Although thus far the localization of these 5-HT receptor subtypes in the brain is largely unknown and further studies are ongoing to better 

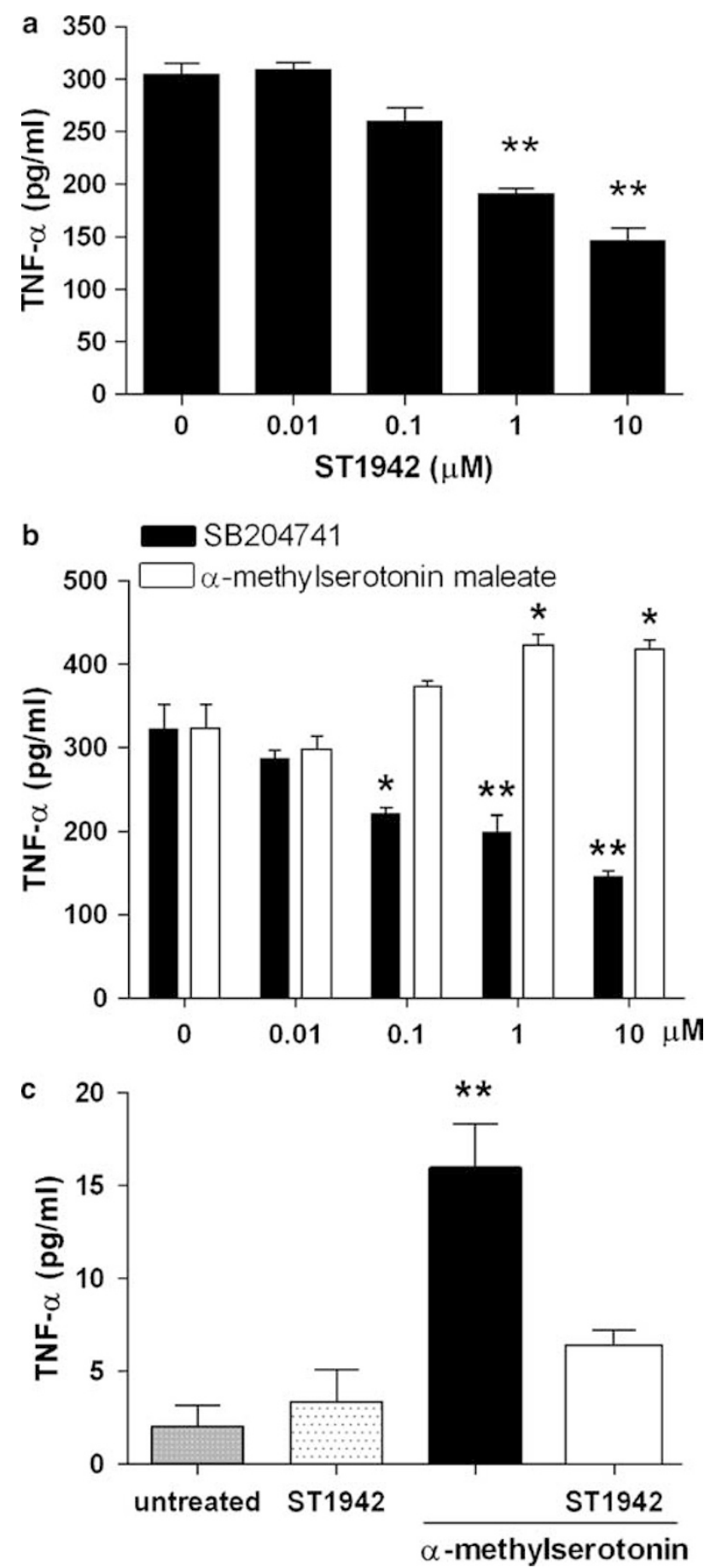

Figure 6 Inhibition of TNF- $\alpha$ release by ST1942 and SB20474I in primary microglia. Primary microglial cells were stimulated with LPS $(50 \mathrm{ng} / \mathrm{ml})$ in the absence or presence of: STI942 (a); SB20474I or $\alpha$ methylserotonin maleate (b). After a I-h incubation, media were collected and analyzed for TNF- $\alpha$ by ELISA. (c) Primary microglial cells were stimulated for I h with $\alpha$-methylserotonin maleate $(50 \mathrm{nM})$ alone or in combination with STI $942(200 \mathrm{nM})$ and TNF- $\alpha$ release was measured as described previously. ${ }^{*} p<0.05$; ${ }^{*} p<0.01$ vs controls (cultures treated with LPS alone in a and b or untreated cells in c). ANOVA with Bonferronicorrected $t$-test. Data shown are means \pm SEM of three determinations.

define their specific function (Leysen, 2004), these data indicate that they may be involved in the control of inflammatory molecule release. Actually serotonin is known

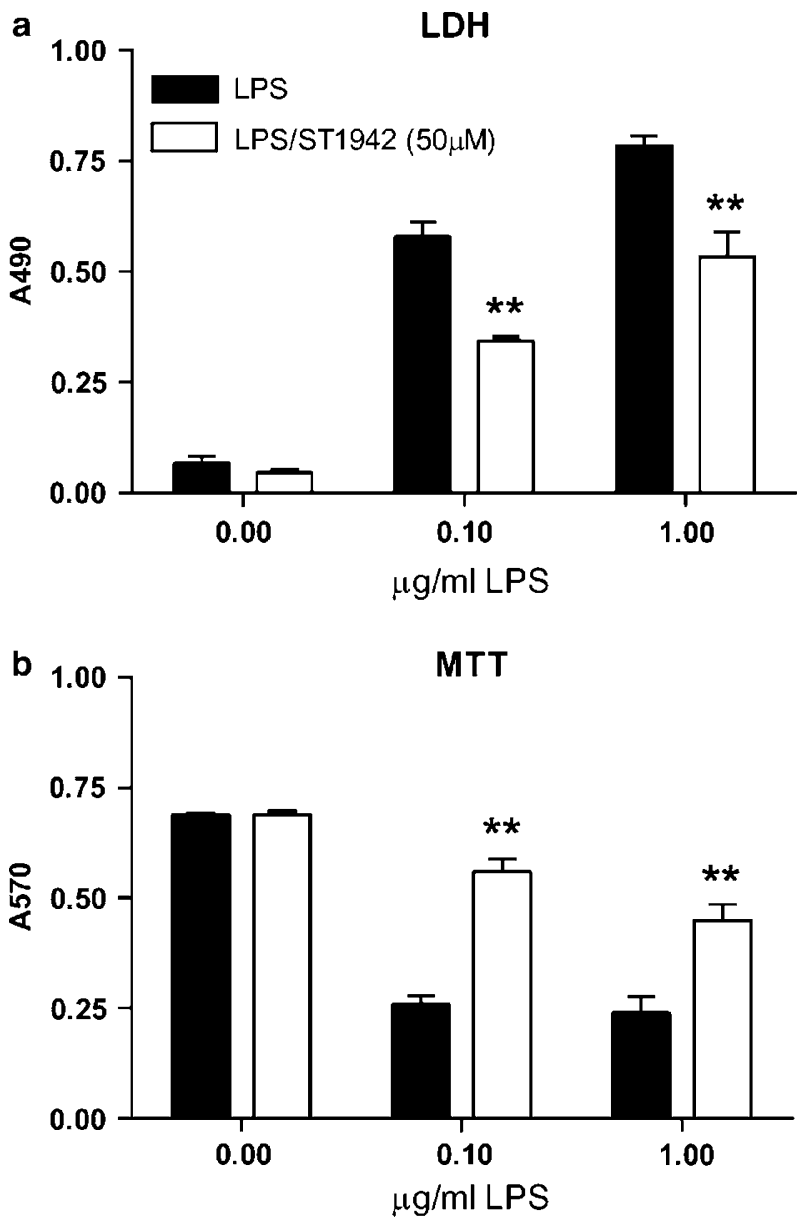

Figure 7 Cytotoxic effect of LPS in cocultures of hippocampal neurons and microglia as assessed by LDH release (a) and MTT assay (b) after $24 \mathrm{~h}$ of treatment with LPS alone $(0.1$ or $\mid \mu \mathrm{g} / \mathrm{ml})$ or in combination with $50 \mu \mathrm{M}$ ST 1942. *** $p<0.0$ I vs cultures treated with LPS alone; ANOVA with Bonferroni-corrected $t$-test. Data shown are means \pm SEM of three determinations.

to be involved in a wide spectrum of immune response modulatory activity (Hellstrand et al, 1993; Kubera et al, 2000, 2005; Young and Matthews, 1995). Interestingly, one recent study proposes a specific involvement of 5-HT2B receptors in the regulation of inflammatory cytokine production from blood cells (Kubera et al, 2005), and a second one shows that stimulation of 5-HT2B receptors leads to a TNF- $\alpha$ converting enzyme-dependent TNF- $\alpha$ release, thus linking activation of these receptors to an increased expression of pro-inflammatory cytokines (Pietri et al, 2005).

The present findings show that ST1942 exerts strong neuroprotective action in ischemia/reperfusion brain injury with a broad time-window of efficacy. Its anti-inflammatory properties, possibly owing to its activity on 5-HT2B receptors, may well account for its antiapoptotic protective actions.

\section{ACKNOWLEDGEMENTS}

We are indebt with Marco Gobbi for critical reading of this paper and helpful discussion and with Stefano Fumagalli for 
the help with immunohistochemistry. PP, GO and PC are employees of Sigma Tau Laboratories. The study was supported by a grant from Sigma Tau.

\section{REFERENCES}

Allan SM, Rothwell NJ (2001). Cytokines and acute neurodegeneration. Nat Rev Neurosci 2: 734-744.

Aloisi F, Ria F, Penna G, Adorini L (1998). Microglia are more efficient than astrocytes in antigen processing and in Th1 but not Th2 cell activation. J Immunol 160: 4671-4680.

Becher B, Prat A, Antel JP (2000). Brain-immune connection: immuno-regulatory properties of CNS-resident cells. Glia 29: 293-304.

Blasi E, Barluzzi R, Bocchini V, Mazzolla R, Bistoni F (1990). Immortalization of murine microglial cells by a v-raf/v-myc carrying retrovirus. J Neuroimmunol 27: 229-237.

Choi DS, Birraux G, Launay JM, Maroteaux L (1994). The human serotonin 5-HT2B receptor: pharmacological link between 5-HT2 and 5-HT1D receptors. FEBS Lett 352: 393-399.

Clark WM, Lessov NK, Dixon MP, Eckenstein F (1997). Monofilament intraluminal middle cerebral artery occlusion in the mouse. Neurol Res 19: 641-648.

Connolly Jr ES, Winfree CJ, Springer TA, Naka Y, Liao H, Yan SD et al (1996). Cerebral protection in homozygous null ICAM-1 mice after middle cerebral artery occlusion. Role of neutrophil adhesion in the pathogenesis of stroke. J Clin Invest 97: 209-216.

De Simoni MG, Perego C, Ravizza T, Moneta D, Conti M, Marchesi $\mathrm{F}$ et al (2000). Inflammatory cytokines and related genes are induced in the rat hippocampus by limbic status epilepticus. Eur J Neurosci 12: 2623-2633.

De Simoni MG, Rossi E, Storini C, Pizzimenti S, Echart C C, Bergamaschini L (2004). The powerful neuroprotective action of C1-inhibitor on brain ischemia-reperfusion injury does not require C1q. Am J Pathol 164: 1857-1863.

De Simoni MG, Storini C, Barba M, Catapano L, Arabia AM, Rossi E et al (2003). Neuroprotection by complement (C1) inhibitor in mouse transient brain ischemia. J Cereb Blood Flow Metab 23: 232-239.

del Zoppo G, Ginis I, Hallenbeck JM, Iadecola C, Wang X, Feuerstein GZ (2000). Inflammation and stroke: putative role for cytokines, adhesion molecules and iNOS in brain response to ischemia. Brain Pathol 10: 95-112.

del Zoppo GJ, Becker KJ, Hallenbeck JM (2001). Inflammation after stroke: is it harmful? Arch Neurol 58: 669-672.

Dirnagl U, Iadecola C, Moskowitz MA (1999). Pathobiology of ischaemic stroke: an integrated view. Trends Neurosci 22: 391-397.

Feuerstein GZ, Wang X (2001). Inflammation and stroke: benefits without harm? Arch Neurol 58: 672-674.

Frijns CJ, Kappelle LJ (2002). Inflammatory cell adhesion molecules in ischemic cerebrovascular disease. Stroke 33: 2115-2122.

Goslin K, Banker G (1990). Rapid changes in the distribution of GAP-43 correlate with the expression of neuronal polarity during normal development and under experimental conditions. J Cell Biol 110: 1319-1331.
Hansen MB, Nielsen SE, Berg K (1989). Re-examination and further development of a precise and rapid dye method for measuring cell growth/cell kill. J Immunol Methods 119: 203-210.

Hellstrand K, Czerkinsky C, Ricksten A, Jansson B, Asea A, Kylefjord $\mathrm{H}$ et al (1993). Role of serotonin in the regulation of interferon-gamma production by human natural killer cells. J Interferon Res 13: 33-38.

Iadecola C, Alexander M (2001). Cerebral ischemia and inflammation. Curr Opin Neurol 14: 89-94.

Kubera M, Kenis G, Bosmans E, Scharpe S, Maes M (2000). Effects of serotonin and serotonergic agonists and antagonists on the production of interferon-gamma and interleukin-10. Neuropsychopharmacology 23: 89-98.

Kubera M, Maes M, Kenis G, Kim YK, Lason W (2005). Effects of serotonin and serotonergic agonists and antagonists on the production of tumor necrosis factor alpha and interleukin-6. Psychiatry Res 134: 251-258.

Leysen JE (2004). 5-HT2 receptors. Curr Drug Targets CNS Neurol Disord 3: 11-26.

Neumann J, Gunzer M, Gutzeit HO, Ullrich O, Reymann KG, Dinkel K (2006). Microglia provide neuroprotection after ischemia. FASEB J 20: 714-716.

Novarino G, Fabrizi C, Tonini R, Denti MA, Malchiodi-Albedi F, Lauro GM et al (2004). Involvement of the intracellular ion channel CLIC1 in microglia-mediated beta-amyloid-induced neurotoxicity. J Neurosci 24: 5322-5330.

Pantoni L, Sarti C, Inzitari D (1998). Cytokines and cell adhesion molecules in cerebral ischemia: experimental bases and therapeutic perspectives. Arterioscler Thromb Vasc Biol 18: 503-513.

Pietri M, Schneider B, Mouillet-Richard S, Ermonval M, Mutel V, Launay JM et al (2005). Reactive oxygen species-dependent TNFalpha converting enzyme activation through stimulation of 5HT2B and alpha1D autoreceptors in neuronal cells. FASEB J 19: 1078-1087.

Piovesan P, Fabrizi C, Carminati P, Lauro GM, Ghirardi O (2003). In vitro cytokine modulatory activity of ST1942, a newly synthetised 2-aminotetraline derivative. In: 33rd Society for Neuroscience Meeting, Washington, DC.

Ruggiero V, Piovesan P, Fabrizi C, Lauro GM, Campo S, Albertoni $\mathrm{C}$ et al (2004). In vivo and in vitro cytokine modulatory activity of newly synthesised 2-aminotetraline derivatives. Shock 21: 77-85.

Schmued LC, Albertson C, Sikker W (1997). Fluoro-Jade: a novel fluorochrome for the sensitive and reliable histochemical localization of neuronal degeneration. Brain Res 751: 37-46.

Storini C, Rossi E, Marrella V, Distaso M, Veerhuis R, Vergani C et al (2005). C1 inhibitor protects against brain ischemiareperfusion injury via inhibition of cell recruitment and inflammation. Neurobiol Disease 19: 10-17.

Touzani O, Boutin H, Chuquet J, Rothwell N (1999). Potential mechanisms of interleukin-1 involvement in cerebral ischaemia. J Neuroimmunol 100: 203-215.

Troglio F, Echart C C, Gobbi A, Pawson T, Pelicci PG, De Simoni MG et al (2004). The Rai (Shc C) adaptor protein regulates the neuronal stress response and protects against cerebral ischemia. Proc Natl Acad Sci USA 101: 15476-15481.

Young MR, Matthews JP (1995). Serotonin regulation of T-cell subpopulations and of macrophage accessory function. Immunology 84: 148-152. 